\title{
FLUIDIZED BEDS AS TURBULENCE PROMOTERS IN THE CONCENTRATION OF FOOD LIQUIDS BY REVERSE OSMOSIS
}

\author{
R. DE BOER, J. J. ZOMERMAN, J. HIDDINK, J. AUFDERHEYDE, \\ W. P. M. VAN SWAAY, and C. A. SMOLDERS
}

\begin{abstract}
Fluidized beds offer a potential improvement of reverse osmosis processes for food liquids, less fouling of the membrane, and reduced cnergy consumption. Our experiments were concerned with tubular systems in which fluidized beds of glass, steel, and lead beads were used. Glass beads appeared to be preferable, since they caused little damage to the membrane. Only with the larger glass beads $(3 \mathrm{~mm})$ did the membrane skin become corrugated, so that the rejection decreased. The permeate flux for Gouda cheese whey was almost equal to that of an empty tube for which the velocity was about thirty times higher. The erosive action of the glass beads on the fouling layer was partially responsible for this effect. For reverse osmosis of skim milk and potato fruit water the bed did not reduce the fouling layer to a sufficient extent and, therefore, had a lower permeate flux than an empty tube.
\end{abstract}

\section{INTRODUCTION}

AFTFR the energy crisis in 1973, reverse osmosis (RO) of cheese whey became a point of interest in the Netherlands. One of the main reasons for this interest was the reduction in energy costs that can be reached by $\mathrm{RO}$, in comparison with the costs of evaporation (De Boer et al., 1977). At the moment a number of industrial plants have been installed which concentrate the Gouda cheese whey two to three times. Concentration is done at the temperature of cheese making (about $30^{\circ} \mathrm{C}$ ) or after cooling to 10 or $18^{\circ} \mathrm{C}$. After this treatment the whey is transported directly to centralized plants, or, occasionally, additional evaporation is carried out. In addition to the dairy industry, the potato starch industry shows growing interest in $\mathrm{RO}$, in order to solve the big effluent problems that are encountered in the northern part of this country (Meindertsma, 1980). In this process the potato fruit water is concentraled to half its volume in a tubular system at ambient temperature, before being processed into denatured potato protein.

Our investigation concerning food liquids was a continuation of the work conducted by Van der Waal et al. (1977), who made use of glass beads in a tubular membrane system for RO of a salt solution. The conclusion drawn from their work was that with a fluidized bed the same mass transfer coefficient can be reached as that in an empty tube, with only about $5 \%$ of the circulation energy. Damage to the membrane surface could not be observed when glass particles were used with a diameter of $0.7 \mathrm{~mm}$ or smaller. In addition to the literature review presented by Van der Waal et al. (1977), a short review of the effects of turbulence promoters in membrane processing of some food liquids is

Authors De Boer and Hiddink are with the Netherlands Institute for Dairy Research, P.O. Box 20,6710 BA Ede (the Netherlands). Author Zomerman is currently with Shell International Petroleum Maatschappij, the Hague. Author Aufderheyde is with Wafilin, Hardenberg, and authors Van Swaay and Smolders are with the Twente University of Technology, Enschede.

0022-1147/80/0006-1522\$02.25/0

$\odot 1980$ Institu te of Food Technologists given here. Lowe and Durkee (1971) used beads of acrylic resin in a plate-and-frame RO equipment for the concentration of orange juice. A threefold flux improvement appeared to be possible, and a certain capability of self cleaning was also mentioned. Peri and Dunkley (1971) used static rods as turbulence promoters, which in the concentration of cottage cheese whey effected a threefold increase in permeate flux. However, they compared the effect of the turbulence promoters with results of empty-tube experiments at velocities of $10-40 \mathrm{~cm} / \mathrm{s}$, while in industrial installations velocities of $\geqslant 2 \mathrm{~m} / \mathrm{s}$ are normal at the moment. In our study we tried to reduce the velocity and thus the energy consumption by using fluidized beds in a specially constructed tubular RO test equipment. Of three food liquids of different composition, sweet Gouda cheese whey, skim milk, and potato fruit water, numerical data about permeate flux and permeate quality were collected. These data were compared with the results obtained in the emptytube experiments at flow rates normally used for industrial installations.

\section{EXPERIMENTAL}

\section{Apparatus}

The test equipment (supplied by Wafilin BV, Hardenberg, the Netherlands) consisted of 20 parallel tubes $1.5 \mathrm{~m}$ in length, each followed by a transparent transport tube of $0.2 \mathrm{~m}$ (Fig. 1). The tubes, in which the tubular membrane with a diameter of $14.8 \mathrm{~mm}$ was contained, were mounted in a vertical position. The celluloseacetate membranes had a rejection for sodium chloride of $92.5 \%$. The maximum membrane area of the equipment was $1.3 \mathrm{~m}^{2}$, which made the test equipment less suitable for concentration experiments. The experiments were therefore carried out at constant volume reduction with recirculation of the permeate. For the comparison between fluidized-bed and empty-tube equipment the number of tubes in the installation was reduced to ten; due to the high velocity of the feed $(2 \mathrm{~m} / \mathrm{s})$ required in the empty tube, only one of the tubes could be used as an empty tube. The fluidized bed particles used were glass, steel, and lead beads. The diameters of the glass beads (supplied by Tamson) were: $0.4,0.7,1.0,1.3,2.0,3.0$, and $4.0 \mathrm{~mm}$, and the mass densities were $2890,3500,2670,2870,2500$,

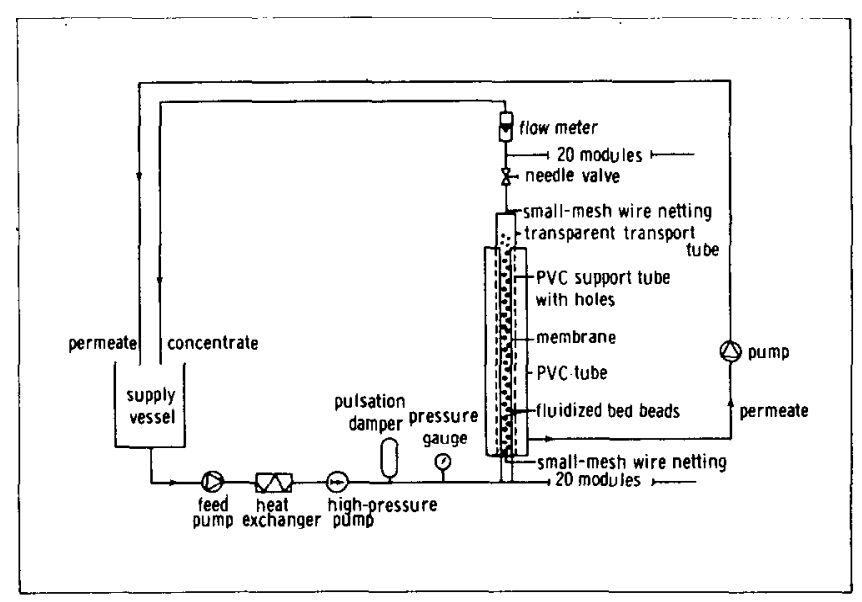

Fig. 1-Fluidized-bed reverse osmosis apparatus. 
2580 , and $2610 \mathrm{~kg} / \mathrm{m}^{3}$, respectively. The steel beads had diameters of 1.0 and $2.5 \mathrm{~mm}$, their mass density being 7640 and $7820 \mathrm{~kg} / \mathrm{m}^{3}$, respectively. The lead beads had a diameter of $3.0 \mathrm{~mm}$ and a mass density of $10400 \mathrm{~kg} / \mathrm{m}^{3}$. Besides the diametcr and type of material, the bed porosity $(\epsilon)$ also varied. It was defined as the volume of the empty tube minus the volume of the beads, divided by the volume of the empty tube.

A critical point in the use of fluidized beds is the starting-up procedure. Prior to each experiment the installation was rinsed with water. The flow rate and pressure were increased slowly, until all the fluidized beds were visible in the transparent transport tube at the desired pressure. During switching over to whey, skim milk or potato fruit water the fluidized beds had to remain visible; meanwhile the pressure (3-4 MPa) and the flow rates were adjusted. After completion of each experiment the installation was rinsed with water and subsequently cleaned with an enzymatic detergent (Tergazym, $0.5 \%$, adjusted to $\mathrm{pH} 8$ with citric acid, temperature $30^{\circ} \mathrm{C}$, period $1 \frac{1}{2} \mathrm{hr}$ ). During cleaning the beds remained fluidized. Then the installation was rinsed again with water and finally disinfected with a sodium hypochlorite solution $(50 \mathrm{mg} / \mathrm{liter}$ active chlorine, period $1 / 2 \mathrm{hr}$ ).

\section{Feed solutions}

Gouda cheese whey, skim milk, and potato fruit water were used as feed solutions. The composition of the cheese whey was roughly $5.5 \%$ total solids, $0.75 \%$ protein, $0.5 \%$ ash, $0.2 \%$ organic salts, and $4.0 \%$ lactose $(\mathrm{pH} 6.5)$. The skim milk contained $8.9 \%$ total solids, $3.4 \%$ protein, $0.7 \%$ ash, $0.2 \%$ organic salts, and $4.6 \%$ lactose, $(\mathrm{pH}$ 6.7 ). The potato fruit water consisted of $5.2 \%$ total solids, $2.9 \%$ protein, $1.2 \%$ ash, and $0.8 \%$ carbohydrates (pH 6.0). The potato fruit water was used directly after manufacture. The skim milk and cheese whey were first pasteurized $\left(67^{\circ} \mathrm{C} / 10 \mathrm{~s}\right.$ and $72^{\circ} \mathrm{C} / 10 \mathrm{~s}$, respectively) and subsequently cooled to $4^{\circ} \mathrm{C}$.

Membrane photographs

The membrane surfaces were studied by means of a scanning electron microscope. Photographs were taken after the membranes had been dried and carbon and gold had been deposited on the membrane surface.

\section{Analytical methods}

Total solids content by drying in an oven at $105^{\circ} \mathrm{C}$.

Protein content by the Kjeldahl method (protein factor 6.38).

Ash concent by drying in an oven at $105^{\circ} \mathrm{C}$ and heating in an electric muffle furnace at $550^{\circ} \mathrm{C}$ for at least $8 \mathrm{hr}$.

Calcium, sodium and potassium contents by flame emission.

Chloride content according to IDF 17A (1972).

Lactose content according to the procedure of Luff-Schoorl (1929).

Bacterial count by the spiral plate method according to Gilchrist et al. (1977), coun ting medium plate count agar with $1 \%$ milk.

The number of population equivalents (PE) was calculated with the formula: $\mathrm{PE} / \mathrm{m}^{3}=\frac{1}{1.80}(\mathrm{COD}+4.57 \mathrm{~N})$, where $\mathrm{COD}$ and $\mathrm{N}$ are both expressed as $\mathrm{mg} / \mathrm{liter}, \mathrm{COD}$ was estimated by a bichromate method according to NEN 3235 5.3.

\section{RESULTS \& DISCUSSION}

Changes in the membrane skin caused by fluidized bed particles

One of the main problems concerned with the use of a fluidized bed in an RO system is the risk of the membrane becoming damaged due to the continuous bombardment by the beads. From the point of view of preventing such dam. age and of limiting energy consumption, beads with a small diameter and a low mass density are desirable. On the other hand, from the viewpoint of mechanical cleaning of the membrane by the fluidized bed, which may be more important with food liquids than with salt solutions, larger and heavier beads which increase the erosive action are to be preferred. These conflicting demands were the reason that the beads were varied as regards mass density and diameter. In addition to these points, the hardness of the beads and the bed porosity may also play a role in the damaging of the membrane. The number of collisions per unit membrane area per unit of time will be proportional to bed porosity. In Table 1 some characteristics of various fluidized beds are given. It is shown that the desired velocity for fluidization is different for glass, steel and lead. The higher the mass density and bed porosity, the higher is the flow velocity required for fluidization. A measure of the damage to the membrane is the total solids content of the permeate. The steel $(\mathrm{d}=2.5 \mathrm{~mm})$ and lead $(\mathrm{d}=3 \mathrm{~mm})$ beads were found to damage the cellulose acetate membranes to such an extent that the total solids content of the permeate was about ten times higher than when glass beads $(d=3$ $\mathrm{mm}$ ) were used. With the use of steel beads the total solids content of the permeate increased within $30 \mathrm{hr}$ from 0.2 to $2.0 \%$, whereas with glass beads the total solids content remained constant at $0.2 \%$ during a process time of $200 \mathrm{hr}$. The relatively good condition of the membrane after $\mathrm{RO}$ of concentrated whey when a fluidized bed of glass beads had been used may be explained by the lower momentum of the particles, which is the result of their low mass density and relatively low velocity (the velocity in Table 1 was calculated on the basis of an empty tube). Hardness and bed porosity seemed to be of less importance.

The damage to the membrane skin after exposure to lead beads is illustrated by the pholographs (Fig. 2a). Figure $2 b$ shows that even after chemical cleaning some deposits are left in the damaged parts. These deposits soon restrict the permeate flux, which in the beginning was higher than that obtained with glass beads. Deposition occurred particularly when heavily fouling feeds, such as skim milk and potato fruit water, were used. Steel beads had about the same effect as lead beads. Glass beads $(\mathrm{d}=3 \mathrm{~mm})$ appeared to cause no serious damage (Fig. 2c), but the skin of the membrane became corrugated. We have the impression that the corrugated skin was formed at the very beginning of the fluidized-bed experiments. This idea is supported by the fact that the total solids content of the permeate did not change under the same process conditions if the process time was increased. A corrugated membrane surface was not found when glass beads with a diameter below $3 \mathrm{~mm}$ were used. It is to be noted that the diameter at which

Table 1-Some characteristics of three fluidized beds used for reverse osmosis of Gouda whey

\begin{tabular}{lccccc}
\hline & $\begin{array}{c}\text { Relative } \\
\text { hardness } \\
\text { (Mohs) }\end{array}$ & $\begin{array}{c}\text { Mass } \\
\text { density } \\
\left(\mathrm{kg} / \mathrm{m}^{3}\right)\end{array}$ & $\begin{array}{c}\text { Superficial } \\
\text { flow } \\
\text { porosity }\end{array}$ & $\begin{array}{c}\text { Belocity } \\
\text { (m/s) }\end{array}$ & $\begin{array}{c}\text { Total solids content } \\
\text { of permeateb after a } \\
\text { certain process time }\end{array}$ \\
\hline $\begin{array}{c}\text { glass } \\
\phi 3 \mathrm{~mm}\end{array}$ & $4.5-6.5$ & $2.5 \times 10^{3}$ & 0.65 & 0.06 & $0.2 \%-200 \mathrm{hr}$ \\
$\begin{array}{c}\text { stee! } \\
\phi 2.5 \mathrm{~mm}\end{array}$ & $5.0-8.0$ & $7.8 \times 10^{3}$ & 0.85 & 0.32 & $2.0 \%-30 \mathrm{hr}$ \\
$\begin{array}{l}\text { lead } \\
\phi 3 \mathrm{~mm}\end{array}$ & 1.5 & $10.4 \times 10^{3}$ & 0.95 & 0.40 & $2.2 \%-60 \mathrm{hr}$ \\
\hline
\end{tabular}

a Hardness of cellulose ace tate is 1.0 .

b Permeate of concentrated whey (16\% TS); initial TS permeate $0.2 \%$. 


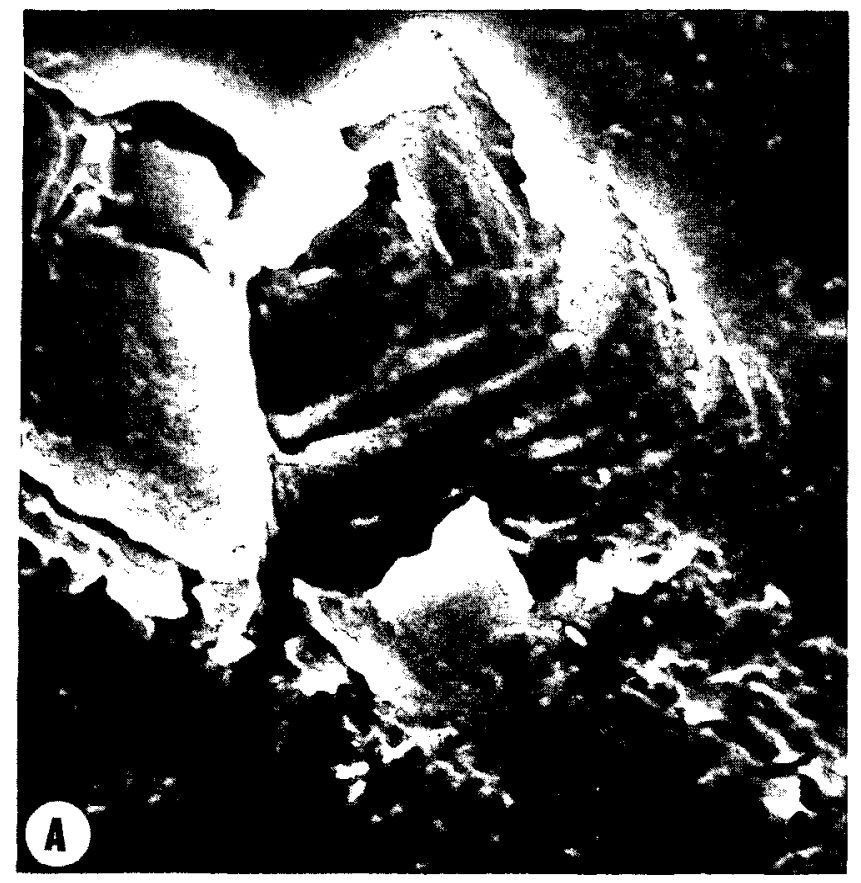

Fig. 2-Photographs of a cleaned membrane skin after reverse osmosis of Gouda cheese whey and skim milk with a fluidized bed after a process time of $150 \mathrm{hr}$ : (A) The damage to the membrane skin caused by lead beads ( $d=3 \mathrm{~mm}, \epsilon=0.95)$, enlargement $150 x$. (B) Deposits in the damaged parts after the use of lead beads $(d=3 \mathrm{~mm}$ $\epsilon=0.95)$, enlargement 1000x. (C) Corrugated membrane skin after the use of glass beads $(d=3 \mathrm{~mm}, \epsilon=0.8)$, enlargement $80 x$.

beads caused damage to the membrane is much larger than in the study of Van der Waal et al. (1977), which was $\leqslant 0.7$ $\mathrm{mm}$. Except for an improvement of the start-up procedure in the present study, it is probable that in the case of food liquids a gel layer acting as a secondary membrane, plays a role in decreasing membrane damage (Hiddink et al., 1980).

Composition of whey permeate in a fluidized bed consisting of glass beads

Because the exposure of the membrane to a fluidized bed of glass beads $(\mathrm{d}=3 \mathrm{~mm}, \epsilon=0.8$ ) may influence the separation efficiency, the composition of whey permeate in comparison with that of whey permeate in an empty tube (velocity $2 \mathrm{~m} / \mathrm{s}$ ) was examined (Table 2). At three levels of total solids content of the whey, the total solids content of the fluidized bed permeate was about twice as high as that obtained with the empty tube equipment. Three quarters of the total solids of both permeates are ash components such as sodium, potassium, and chloride. This difference in total solids may have been caused by the corrugated membrane skin (Fig. 2c), which suggests stretching of the membrane and, consequently, an adverse effect on the rejection. So, after a process time of $200 \mathrm{hr}$ the glass beads werc removed from the installation and the rejection was determined. The sodium chloride rejection of the membrane had diminished from $92.5 \%$ to $85 \%$, which means that, due to the continuous bombardment of the glass beads, the membrane had become more open.

Additional desalting (mainly monovalent ions) may be expected when Gouda cheese whey is concentrated in a fluidized bed RO equipment, which is not normally considered a disadvantage. A drawback is, however, that the higher content of organic material in the permeate adversely influences the costs of discharging. In the Nether-
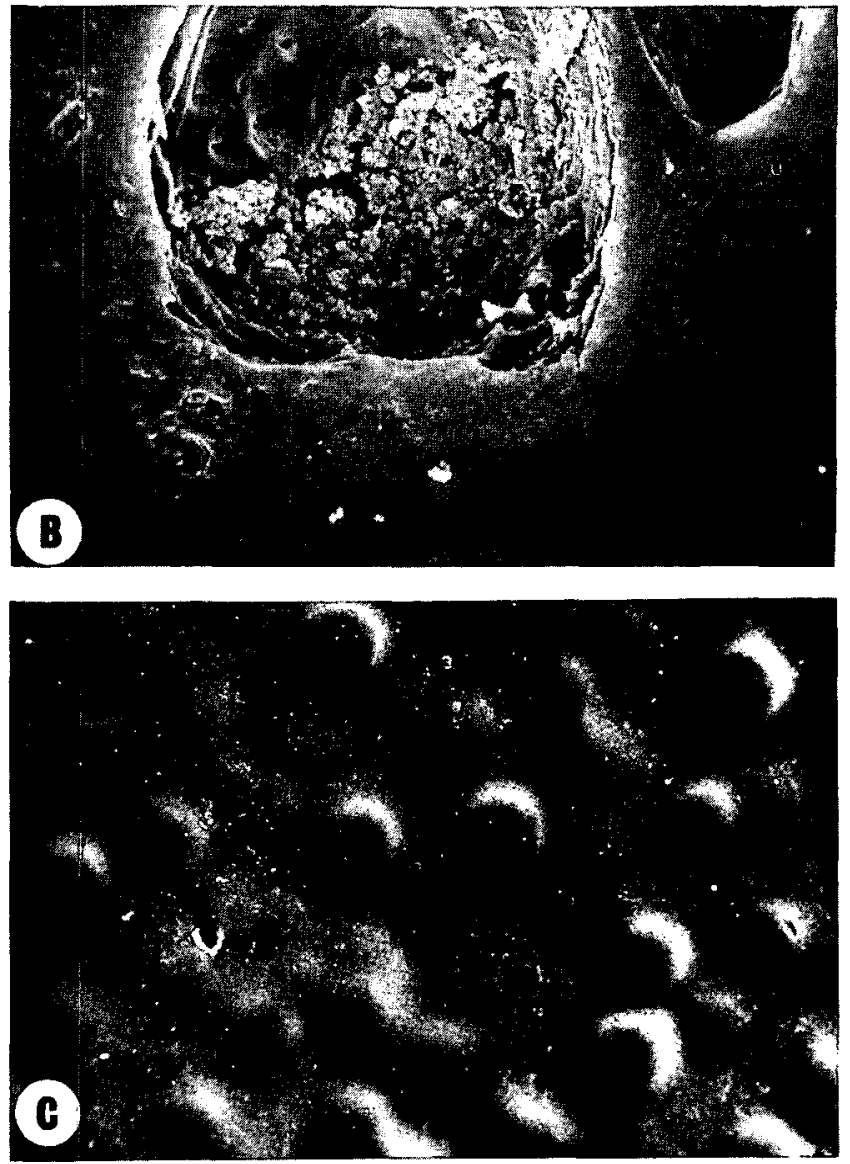

lands the "Population Equivalent" is used as a unit of pollution, which is calculated on the basis of COD and nitrogen content. The population equivalents of the two permeates differed less than the difference in total solids content. The difference of a factor of 2 is found again when the COD results of the fluidized-bed and empty-tube experiments are compared, the nitrogen content remaining the same in both cases. A similar effect was achieved with the open DDS 985 and the tight DDS 995 membrane, which had the same nitrogen loss (De Boer et al., 1977). This loss is caused by a

Table 2-The composition of Gouda whey permeate of a fluidized bed (glass beads $\phi 3 \mathrm{~mm}, \epsilon=0.65$ ) in comparison with an empty tube system $(\mathrm{V}=2 \mathrm{~m} / \mathrm{s})$ at three total solids levels of whey

\begin{tabular}{|c|c|c|c|c|c|c|c|}
\hline & & \multicolumn{2}{|c|}{$\%$} & \multicolumn{3}{|c|}{$\mathrm{mg} / 100 \mathrm{l}$} & \multirow[b]{2}{*}{$P E^{*} / \mathrm{m}^{3}$} \\
\hline & & TS & ash & $\mathrm{Ca}$ & $\mathrm{K}+\mathrm{Na}$ & $\mathrm{Cl}$ & \\
\hline whey - & $\begin{array}{l}5.6 \% \text { TS } \\
\text { fluid bed } \\
\text { empty tube }\end{array}$ & $\begin{array}{l}0.08 \\
0.04\end{array}$ & $\begin{array}{l}0.06 \\
0.03\end{array}$ & $\begin{array}{l}0.1 \\
0.1\end{array}$ & $\begin{array}{l}26 \\
13\end{array}$ & $\begin{array}{l}25 \\
11\end{array}$ & $\begin{array}{l}3.1 \\
2.5\end{array}$ \\
\hline whey - & $\begin{array}{l}7.5 \% \text { TS } \\
\text { fluid bed } \\
\text { empty tube }\end{array}$ & $\begin{array}{l}0.09 \\
0.05\end{array}$ & $\begin{array}{l}0.07 \\
0.03\end{array}$ & $\begin{array}{l}0.1 \\
0.1\end{array}$ & $\begin{array}{l}33 \\
16\end{array}$ & $\begin{array}{l}33 \\
16\end{array}$ & $\begin{array}{l}3.1 \\
2.5\end{array}$ \\
\hline whey - & $\begin{array}{l}21.9 \% \text { TS } \\
\text { fluid bed } \\
\text { empty tube }\end{array}$ & $\begin{array}{l}0.40 \\
0.22\end{array}$ & $\begin{array}{l}0.31 \\
0.18\end{array}$ & $\begin{array}{l}0.5 \\
0.3\end{array}$ & $\begin{array}{r}154 \\
86\end{array}$ & $\begin{array}{r}149 \\
81\end{array}$ & $\begin{array}{l}8.2 \\
5.4\end{array}$ \\
\hline
\end{tabular}

* $P E=$ Population Equivalen

$\mathrm{PE} / \mathrm{m}^{3}=\frac{1}{180}(\mathrm{COD}+4.57 \mathrm{~N}) ; \mathrm{COD}$ and $\mathrm{N}$ are both expressed as mg/liter. 
part of the NPN fraction, the urea. Obviously the molecular structure of urea is such that it is capable of passing the open and the tight membrane.

Influence of bed porosity and glass bead diameter on the permeate flux

Since the permeate flux is an important factor from an economical point of view, the influence of glass beads on the permeate flux was studied under various conditions. Gouda cheese whey was used as feed solution, mostly at a process temperature of $10^{\circ} \mathrm{C}$. In Figure 3 the permeate flux is given as a function of bed porosity. At a low value $(0.52)$ the porosity of a packed bed is approached and at a high value (1.0) that of an empty tube. Below a bed porosity of 0.65 the bed is less stable, because then bridge-like particle agglomerates are formed, and also the risk of damage to the membrane may increase. The velocity varies according to the bed porosity; for $3 \mathrm{~mm}$ glass beads and at a porosity of $0.52,0.65$, and 0.90 the superficial flow velocity is 0.025 , 0.06 , and $0.16 \mathrm{~m} / \mathrm{s}$, respectively. Figure 3 shows that the permeate flux at a volume reduction of $0 \%$ is more favorable with $3 \mathrm{~mm}$ glass beads than with 0.7 and $2.0 \mathrm{~mm}$ beads. Obviously, the momentum of the beads plays an important role. With $4 \mathrm{~mm}$ beads the flux is less favorable than with $3 \mathrm{~mm}$ beads; here the ratio bead diameter/tube diameter seems too large to ensure good results. The graph with $0 \%$ volume reduction and $3 \mathrm{~mm}$ beads indicates that a bed porosity between 0.65 and 0.85 gave the highest flux figures. Comparison of these figures with those of a packed bed $(\epsilon=0.52)$ gives a rough idea of the extent of the specific action of the fluidized bed. The increased permeate flux may be attributed to increased mass transfer and ero-

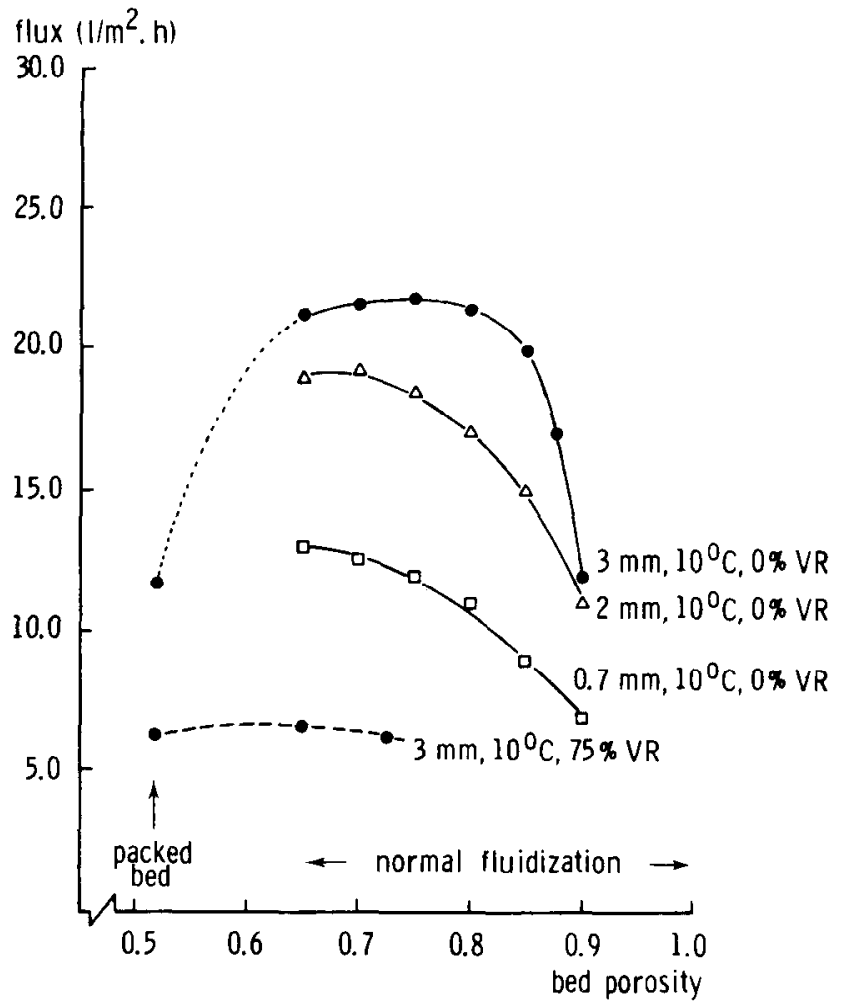

Fig. 3-Reverse osmosis of Gouda whey in a fluidized-bed system carried out under recirculation of permeate and a pressure of $4 \mathrm{MPa}$. The influence of bed porosity and diameter of the glass beads on permeate flux is indicated, as well as the influence at two volume reductions for $3 \mathrm{~mm}$ glass beads. sive action. A further understanding of the erosive action may be obtained when the results of fluidized-bed experiments are compared with those of empty-tube experiments at high velocity. Figure 4 shows the permeate flux as a function of the mass transfer coefficient for lactose. The mass transfer coefficient for the empty tube was calculated from the known mass transfer relationship in tubes under turbulent conditions (Rautenbach and Rauch, 1977), and the coefficient for the fluidized bed was calculated according to Van der Waal et al. (1977). For the fluidized bed the coefficient lies between narrow limits at about $8.5 \times 10^{-6}$ $\mathrm{m} / \mathrm{s}$. For bed porosity 0.52 (approaching the packed bed) and 0.90 (approaching the empty tube) we find permeate fluxes almost equal to those in an empty tube at equal mass transfer coefficient, which can be understood from the fact that in both cases the erosive action will disappear. $\Lambda t$ a bed porosity of $0.65-0.75$ the permeate flux is about the same as that at a mass transfer coefficient twice as high as that obtained in an empty tube at a velocity of about $2 \mathrm{~m} / \mathrm{s}$, which suggests the specific action mentioned. Thus, the erosive action doubles the perneate flux at the same mass transfer coefficient.

Apart from unconcentrated whey, Gouda whey was also used, at a volume reduction of $75 \%$, in the fluidized-bed experiments with $3 \mathrm{~mm}$ glass beads. The curve for concentrated whey is flat, and there is no difference between results gained with the packed bed and those obtained at a bed porosity of $0.65-0.75$ (Fig. 3 ). The effect of the erosive action has disappeared. During concentration the viscosity of the whey increases, at a temperature of $10^{\circ} \mathrm{C}$, from $1.5 \mathrm{mPa} \cdot \mathrm{s}$ at a volume reduction of $0 \%$ to $3.2 \mathrm{mPa} \cdot \mathrm{s}$ at a volume reduction of $75 \%$. This increase slows down the velocity of the beads proportionally and the lower velocity decreases in its turn the momentum of the glass beads. This lower momentum may explain the disappearance of the erosive action. In Figure 5 the flux figures of the fluidized bed are compared with those of an empty tube at three different volume reductions. At high volume reductions al-

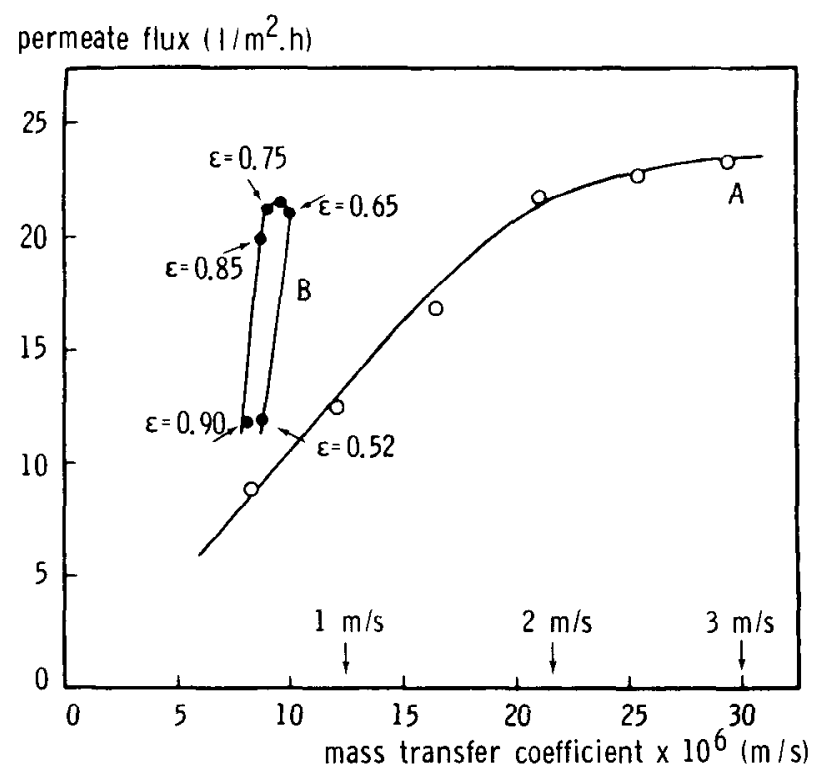

Fig. 4-Relationship between permeate flux and mass transfer coefficient (for lactose) for reverse osmosis of Gouda cheese whey at a temperature of $10^{\circ} \mathrm{C}$ and a pressure of $4 \mathrm{MPa}$. The velocities refer to those in an empty tube. (A) Experimental in an empty-tube, highvelocity system. (B) Experimental with a fluidized-bed system with g/ass beads $3 \mathrm{~mm}$. 


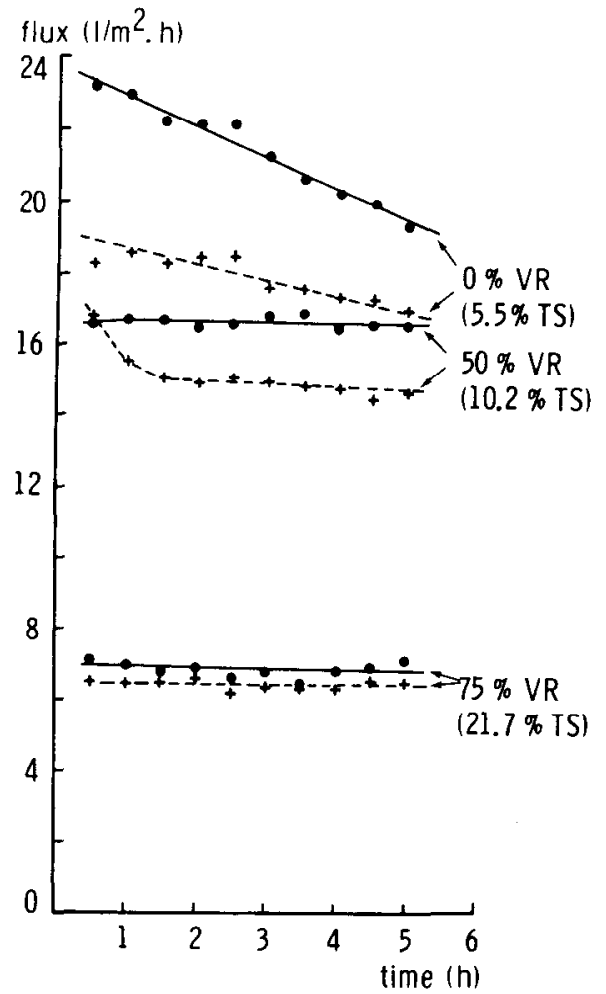

Fig. 5-Reverse osmosis of Gouda whey at a process temperature of $11^{\circ} \mathrm{C}$ and a pressure of $4 \mathrm{MPa}$ in a fluidized bed (d g/ass beads $=3$ $\mathrm{mm}, \epsilon=0.65)$ and an empty tube $(v=2 \mathrm{~m} / \mathrm{s})$ at various volume

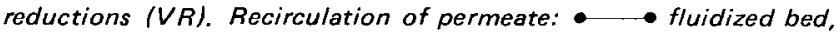
+-----+empty tube.

most no difference is observed. In the concentrated whey with $21.7 \%$ total solids, both the erosive action of the beads and the high velocity along the membrane in an empty tube seem to be insufficient to control the fouling (see also Fig. $3,75 \%$ volume reduction). At a volume reduction of $0 \%$ the flux obtained with the fluidized bed is high at first, but decreases gradually, so that the difference from that obtained with the empty tube becomes smaller. This indicates that, especially for the fluidized bed at $0 \%$ volume reduction, the fouling cannot be fully controlled during prolonged process time. It should be realized, however, that one of the advantages of a fluidized bed, the much lower superficial velocity and hence reduced energy consumption, still holds.

\section{Permeate flux and bacterial counts in long-term experiments}

Lowe and Durkee (1971) observed in their experiments with orange juice that turbulence promoters cause a certain amount of self cleaning of the membrane. This is of interest from the point of view of saving on cleaning agents and increasing the process time which is available for concentration. Long-term experiments were carried out with $3 \mathrm{~mm}$ glass beads and a bed porosity of 0.65 , since preliminary experiments had shown that in the long run a porosity of 0.65 was more effective than 0.75 . Furthermore, the control of the fluidized bed appeared to be very important, a collapse of the bed causing rapid fouling of the membrane due to the low velocity of the fluid. Tests were made with Gouda whey having total solids contents of $7.5 \%$ and $15.3 \%$. In long-term experiments (up to $60 \mathrm{hr}$ without cleaning) with whey of $7.5 \%$ total solids, the flux could be restored by releasing the pressure for a few minutes every 5 hr (Fig. 6). Furthermore, the equipment was rinsed and sterilized with a solution of $50 \mathrm{mg} /$ liter active chlorine every $15 \mathrm{hr}$. The difference in permeate flux between the fluidized-bed and the empty-tube equipment which diminished during a $15-\mathrm{hr}$ run, increased after this treatment in such a way that the permeate flux obtained with the fluidized bed became higher again. The restoration of the permeate flux could be observed only if rinsing and sterilization were carried out at low pressure. Probably in this way the fouling layer, or part of it, could be removed instead of being pressed on to the membrane. Figure 6 shows that by taking these measures the permeate flux is the same after $60 \mathrm{hr}$ as it was in the beginning. In contrast to Figure 5 , the results of the fluidized-bed experiments with whey of $15.3 \%$ total solids content were somewhat less favorable than those of the empty-tube tests. It may be that during starting-up the
Fig. 6-The permeate flux of Gouda whey at two total solids levels (recirculation of permeate) in a fluidized-bed RO system compared with the flux of an emp. ty tube during long-term experiments. In addition to the flux, bacterial counts are indicated. Process conditions: $11^{\circ} \mathrm{C}$, $4 \mathrm{MPa}$ (starting up at $3.5 \mathrm{MPa}$ ). $\uparrow$ without pressure for $5 \mathrm{~min}, \uparrow \uparrow$ rinsing and sterilizing at low pressure for $30 \mathrm{~min}$. $\longrightarrow$ - fluidized bed: (d glass beads $=3$ $m m, \epsilon=0.65) ; x-\cdots-\cdots$ empty tube: $v=2$ $\mathrm{m} / \mathrm{s}$.

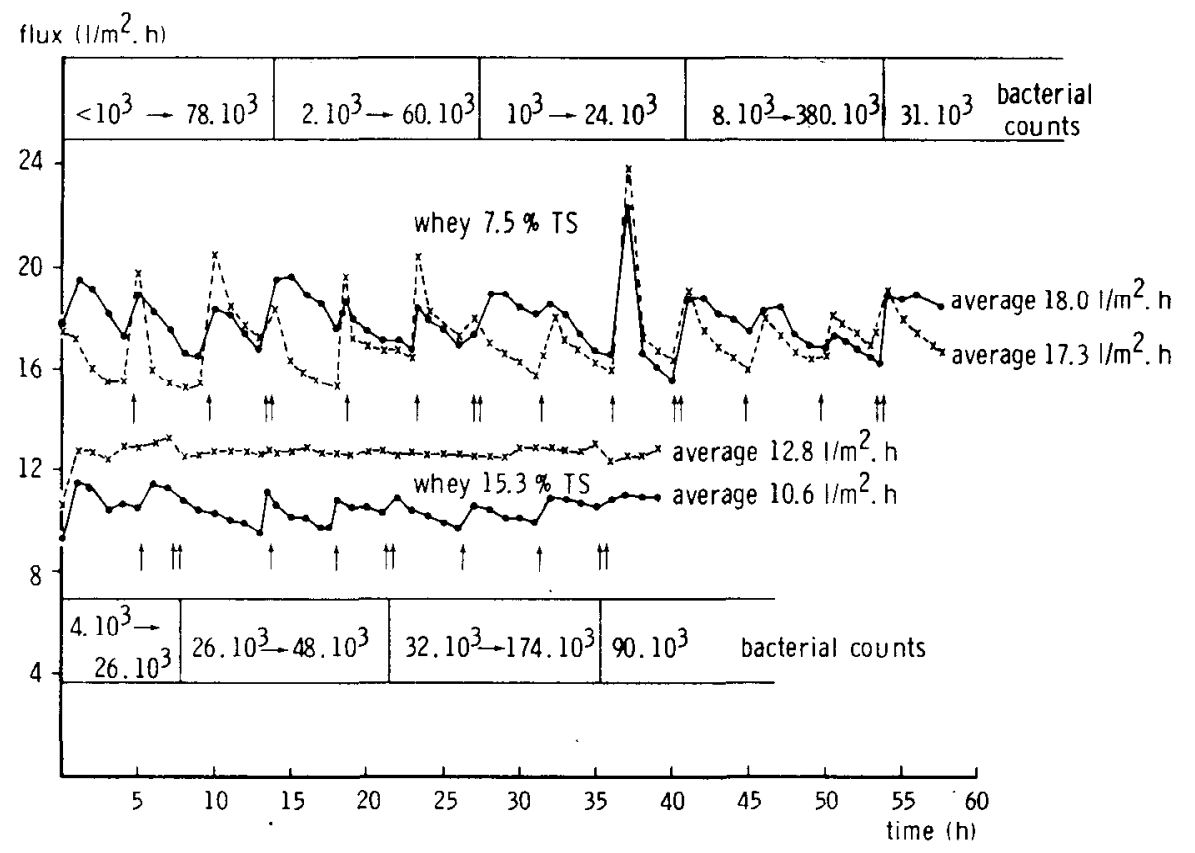


Table 3-The permeate flux in a fluidized bed reverse osmosis system (glass beads $\phi 3 \mathrm{~mm}, \epsilon=0.65$ ) of Gouda whey, skim milk and potato fruit water compared with the flux in an empty tube system ("Wafilin"). The flux was measured after a process time of $4 \mathrm{hr}$ at a volume reduction of $50 \%$

\begin{tabular}{|c|c|c|c|c|c|}
\hline \multirow[b]{2}{*}{ Raw materials } & \multirow[b]{2}{*}{ System } & \multirow{2}{*}{$\begin{array}{l}\text { Permeate } \\
\text { flux (liter/ } \\
\mathrm{m}^{2} \cdot \mathrm{hr} \text { ) }\end{array}$} & \multicolumn{3}{|c|}{$\begin{array}{c}\text { Optimum } \\
\text { process conditions }\end{array}$} \\
\hline & & & $\begin{array}{c}V \\
(\mathrm{~m} / \mathrm{s})\end{array}$ & $\begin{array}{c}\mathrm{P} \\
(\mathrm{MPa})\end{array}$ & $\begin{array}{c}\mathrm{T} \\
\left({ }^{\circ} \mathrm{C}\right)\end{array}$ \\
\hline $\begin{array}{l}\text { whey } \\
\qquad(10.6 \% \text { TS) }\end{array}$ & $\begin{array}{l}\text { fluidized bed } \\
\text { empty tube } \\
\text { fluidized bed } \\
\text { empty tube }\end{array}$ & $\begin{array}{l}16.6 \\
15.5 \\
17.2 \\
15.2\end{array}$ & $\begin{array}{l}0.1 \\
2.6 \\
0.1 \\
2.6\end{array}$ & $\begin{array}{l}4 \\
4 \\
4 \\
4\end{array}$ & $\begin{array}{l}10 \\
10 \\
30 \\
30\end{array}$ \\
\hline $\begin{array}{l}\text { skim milk } \\
\qquad(15.8 \% \text { TS })\end{array}$ & $\begin{array}{l}\text { fluidized bed } \\
\text { empty tube }\end{array}$ & $\begin{array}{r}9.6 \\
12.5\end{array}$ & $\begin{array}{l}0.1 \\
2.6\end{array}$ & $\begin{array}{l}3 \\
3.5\end{array}$ & $\begin{array}{l}30 \\
30\end{array}$ \\
\hline $\begin{array}{l}\text { potato fruit water } \\
(9.4 \% \text { TS })\end{array}$ & $\begin{array}{l}\text { fluidized bed } \\
\text { empty tube }\end{array}$ & $\begin{array}{r}7.1 \\
12.5\end{array}$ & $\begin{array}{l}0.1 \\
2.6\end{array}$ & $\begin{array}{l}3 \\
4\end{array}$ & $\begin{array}{l}25 \\
25\end{array}$ \\
\hline
\end{tabular}

conditions in the fluidized bed were not quite optimal. As the effects of pressure release and disinfecting rinse were less pronounced with the more concentrated whey, this difference could not be eliminated.

Another part of the investigation was concerned with the bacterial count of the whey, an important factor from the point of view of quality control. As the empty tube was part of the fluidized-bed installation the results could not be distinguished from those obtained with the tubes with 3 $\mathrm{mm}$ glass beads. The determinations indicate that there is a certain increase in bacterial count during every 15 -hr run (Fig. 6). The counts are reasonably low, if it is taken into account that the sanitary aspects of the test equipment are not optimal and that the feed was circulated for $15 \mathrm{hr}$, which is much longer than in industrial plants.

Comparison of the permeate flux of whey,

skim milk and potato fruit water

According to Hiddink et al. (1980), Gouda cheese whey at a process temperature of $10^{\circ} \mathrm{C}$ and a velocity $\geqslant 2 \mathrm{~m} / \mathrm{s}$ is a low-fouling liquid. For this reason the fluidized-bed experiments included liquids which gave more serious fouling problems. As well as double-concentrated whey at a temperature of $30^{\circ} \mathrm{C}$, skim milk ( $80 \%$ of the protein consists of casein micelles) and potato fruit water (50\% of the protein is easily coagulable) were chosen. Due to limitations of the fluidized-bed test equipment, control experiments with the empty tube were carried out in a separate installation (Wafilin). In the empty-tube experiments optimum process conditions were chosen to restrict fouling as far as possible. The process conditions for skim milk given in Table 3 were taken from Hiddink et al. (1980) and those for potato fruit water from Meindertsma (1980). For the sake of comparison the whey experiments with the empty tube were also carried out at a velocity of $2.6 \mathrm{~m} / \mathrm{s}$.

As may be expected from previous experiments with whey and with twice concentrated whey, the fluidized bed had a somewhat higher permeate flux than the empty tube, both at $10^{\circ} \mathrm{C}$ and at $30^{\circ} \mathrm{C}$ (Table 3 ). Furthermore, there was no great difference between the flux at $10^{\circ} \mathrm{C}$ and that at $30^{\circ} \mathrm{C}$. At a process temperature of $30^{\circ} \mathrm{C}$, pretreatment of the whey is important to prevent fouling of the membrane, particularly at a volume reduction of $50 \%$, as then the solubility limit of the calcium phosphate is exceeded and a deposit may be formed on the membrane. The pretreatment consisted in concentrating the whey to $50 \%$ volume reduction at $10^{\circ} \mathrm{C}$ and subsequently heating it to $30^{\circ} \mathrm{C}$ in a tank. This method is less effective than decalcification by ion exchange, by decreasing the $\mathrm{pH}$ from 6.5 to 6.1 , or by a

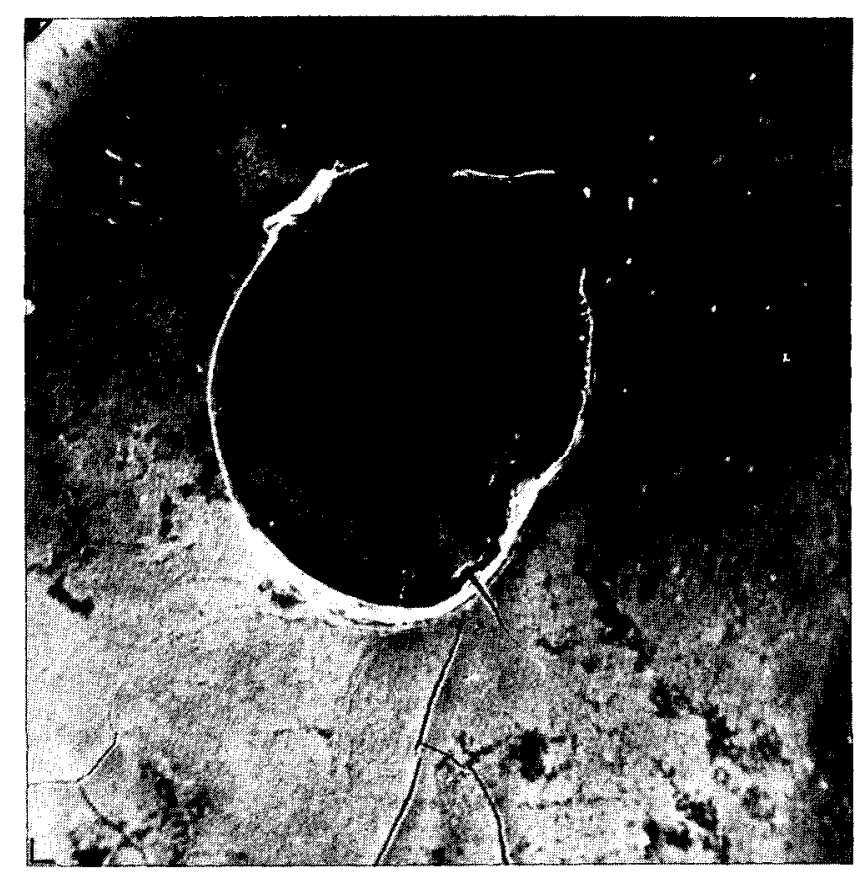

Fig. 7-Photograph of an uncleaned membrane skin after reverse osmosis of skim milk with a fluidized bed of glass beads $(d=3 \mathrm{~mm}$, $\epsilon=0.75)$, enlargement $25 x$.

heat treatment at $65^{\circ} \mathrm{C}$ for $15 \mathrm{~min}$ (Hiddink and De Boer, 1979). For skim milk and potato fruit water, the fluidized bed ( $3 \mathrm{~mm}$ glass beads, bed porosity 0.65 ) had a considerably lower permeate flux than did the empty tube under optimum process conditions (Table 3 ). In the fluidized-bed system the pressure was reduced to $3 \mathrm{MPa}$, in order to restrict the permeate flux and to prevent serious fouling followed by rapid flux decline. Obviously, this fluidized bed is less suitable for preventing the fouling of the membrane than is the empty tube. Probably the momentum delivered by the glass beads is not high enough to reduce the fouling layer. For decreasing the fouling, a material with a somewhat higher mass density than glass may be more useful. It may be expected that with such a material the optimum pressure will be higher and the permeate flux will increase! The photograph (Fig. 7) shows an uncleaned membrane after RO of skim milk; the fouling layer with an imprint of a glass bead is very clear. In this type of fouling the protein may be of importance; skim milk and potato fruit water have a relatively high protein content of about $3 \%$. Skudder et al. (1977) mentioned that in RO of skim milk the casein micelles are mainly responsible for the deposit on the membrane due to limited back diffusion especially at low flow velocities.

\section{PRACTICAL IMPLICATIONS}

\section{\& ENERGY CONSIDERATIONS}

A TUBULAR fluidized-bed reverse-osmosis system is more suitable for the concentration of Gouda cheese whey than for that of more fouling liquids, such as skim milk and potato fruit water. Glass beads with a diameter of $3 \mathrm{~mm}$ and a fluidized bed with a porosity of 0.65 gave the highest permeate flux.

As contrasted with the normal system, the modules in a fluidized-bed system are framed in a vertical position. Due to the weight of the liquid column and of the glass beads $\left(3.5 \mathrm{~kg}\right.$ per $\mathrm{m}^{2}$ membrane area) there is an additional pres- 
sure drop of about $0.016 \mathrm{MPa} / \mathrm{m}$ tube length. This influences the system design, which means that more tubes have to be operated in parallel. One of the critical points in a fluidized-bed system is accurate control of the fluidization, which necessitates complicated control equipment. According to the energy efficiency relation of Van der Waal et al. (1977), for a fluidized-bed system a saving in circulation energy of about $90 \%$ can be achieved. In addition to a circulation pump, a high-pressure pump is necessary. In a normal system the high-pressure pump, which brings the liquid to a pressure of about $4 \mathrm{MPa}$, consumes about $45 \%$ of the total energy. So, in a fluidized-bed system a saving of approximately $50 \%$ on total electricity costs, in comparison with the costs of a normal system, can usually be reached. The fluidized-bed system, besides saving on energy, might also save on cleaning costs, as a result of the lower cleaning frequency and the smaller quantity of detergent (reduction about $30 \%$ ) required per treatment. However, a lower cleaning frequency when whey is processed at $10^{\circ} \mathrm{C}$ is possible only if additional measures are taken, such as releasing the pressure for a few minutes every $5 \mathrm{hr}$, and rinsing and sterilizing at low pressure, for instance every $15 \mathrm{hr}$. A disadvantage is the somewhat higher pollution value of the permeate. This value-calculated on the basis of COD and nitrogen-rose to a factor 1.5. Further development will be necessary before the system has reached the industrial stage. In the present work, for example, more data will have to be provided about the useful life of the membranes.

\section{REFERENCES}

De Boer, R., De Wit, J.N., and Hiddink, J. 1977. Processing of whey by means of membranes and some applications of whey protein concentrate. J. Soc. Dairy Tech. 30:112.

Gilchrist, J.E., Donnelly, C.B., Peeler, J.T., and Campbell, J.E. 1977. Collaborative study comparing the spiral plate and aerobic plate count methods. J. Assn. Off. Anal. Chem. 60: 807.

Hiddink, J. and De Boer, R. 1979. Concentration of milk and whey by reverse osmosis. Second International Congress on Engineering and Food, Helsinki, August 27-31.

Hiddink, J., De Boer, R., and Nooy, P.F.C. 1980. Reverse osmosis of dairy liquids. J. Dairy Sci. 63: 204.

Lowe, E. and Durkee, E.L. 1971 Dynamic turbulence promotion in reverse osmosis processing of liquid foods. J. Food Sci. 36: 31. Luff-Schoorl, N. 1929. Suikertitratie. Chem. Weekblad 26: 130.

Meindertsma, G.W. 1980. Membraanfiltratie bij de verwerking van nevenprodukten van een aardappelmeelfabriek. Polytechn. tijdschr./Procestechn. 35: 35

Peri, C. and Dunkley, W.I. 1971. Reverse osmosis of cottage cheese whey. 2. Influence of flow conditions. J. Food Sci. 36: 395.

Rautenbach, $R$, and $R$ auch, $K ., 1977$. Ultrafiltration und Umkehrosmose. Grundlagen und Technologie. Chem. Ing. Techn. 49:223.

Skudder, P.J., Glover, F.A., and Green, W.L. 1977. An examination of the factors affecting the reverse osmosis of milk with special reference to deposit formation. J. Dairy Res. 44: 293.

Van der Waal, M.J., Van der Velden, P.M., Koning, J., Smolders, C.A., and Van Swaay, W.P.M. 1977. Use of fluidized beds as turbulence promoters in tubular membrane systems. Desalination 22: 465.

Ms received 2/23/80; revised 5/23/80; accepted 5/30/80

Presented at the Symposium "Neue Aspekte der Ultrafiltration und Reversosmose," held in Vienna (Austria) on May 21-22, 1979. The authors thank Mr. M.A. de Jongh, Twente University of Technology, Enschede (the Netherlands) for preparing the electron micrographs, and Mr. K.G. de Noord, "AVEBE," Veendam (the Netherlands), who provided the equipment for the manufacture of fresh potato fruit water.
Inter-Society/Agency Committee on Microbiological Methods for Foods, Ed. Speck, M.L. American Public Health Associa-

tion.
Ngaba. P.R. and Lee, J.S. 1979. Fermentation of cassava (Manihot Sculenta Crantz). J. Food Sci. 44(5): 1568 .

Schoch, T.J, 1964. "Methods in Carbohydrate Chemistry," Vol. 4 "Starch," Ed. Whistler, R.L. Academic Press, New York and London

Schoch, T.J. and Maywald, E.D. 1956. Microscopic examination of modified starches. Anal. Chem. 28:382.

Sharpe. E. and Fryer. T.F. 1966. "Identification Methods for Microbiologists," Part A. Academic Press, London, New York.

Shipman, L. 1967. "Starch Chemistry and Technology," Vol. 12, "Industrial aspects," Ed. Whistler, R.L. Academic Press, New York and London.

Smith, O., de Buckle, T., Sandoval, A.M., and González, G.E. 1979 Production of precooked corn flours for Arepa making using an extrusion cooker. J. Food Sci. 44: 816
Von Ceh, M., Stropmick, C. and Leskovar, S. 1976. Potentiometric determination of molecular weights of starches. Die Stärke 28 : 51.

Ms received $7 / 4 / 79 ;$ revised $4 / 10 / 80$; accepted 4/18/80.

This work was sponsored by the Organization of American States and by the Instituto de Investigaciones Tecnolögicas, Bogotá, Colombia.

The authors express their gratitude to the Institute for Technology and Storage of Agricultural Products from Israel for its cooperation in the Scanning Electron Microscope studies and photomicrographs.

NUTRIENT RETENTION IN RETORTABLE POUCHES. . From page 1516

Teixeira, A.A., Dixon, J.R., Zahradnik, J.W.; and Zinsmeister, G.E. 1969. Computer optimization of nutrient retention in the thermal processing of conduction heated foods. Food Technol. 23(6): 845 .

Teixeira, A.A., Stumbo, C.R., and Zahradnik, J.W. 1975. Experimental evaluation of mathematical and computer models for thermal process evaluation. J. Food Sci. 40:653.

Terajima, $Y .1975$. Over-all heat transmission from the heating medium (steam and water) to the content of the retortable pouch. Canners J. 54(1): 73 .

Yamaguchi, K. 1974. Concerning retort sterilization of film-packaged foods. New Food Ind. 13(7): 55
Yamaguchi, K., Ikushima, F., Komatsu, Y., and Kishimoto, A, 1971. Calculations of the heat sterilization of packaged "Mochi" rice cake using the General Melhod. J. Food Sci. Technol. 18(2): 75.

Yamano, Y. and Komatsu, Y. 1969. Sterilization of foods in flexíble packages. Part 1 . Heat characteristics of a pilot retort for sterilipackages. Part 1. Heat characteristics of a pilot retort for sterition of flexible packages. J. Food Sci. Technol. 16(3): 113 .

Yamano, Y., Komatsu, Y., and Iregami, Y. 1969. Sterilization of amano, Y., Komatsu, Y., and Iregami, Y. 1969. Sterilization of rate and storage test of several packaged foods. J. Food Sci. Technol. 16(3): 119 .

Ms received 2/21/80; accepted 5/24/80. 